\title{
The Exciting Conflict: \\ The Rhetoric of Pornography and Anti-Pornography
}

\section{Jonathan Elmer}

D ornography is, once again, something of a hot item. The legal battles recently fought in Minneapolis, Indianapolis, and elsewhere have renewed interest in the issue, even a sense of pressing urgency. A presidential commission, with Attorney General Meese's blessing, continues to sound the alarm. For a while, The Village Voice seemed to have appointed itself propagandist for the anti-censorship crusade, while such national publications as The New Republic, Harper's, and Newsweek have offered cover articles in the past few years that take a less definite stance. ${ }^{1}$ Debates over pornography-and, more generally, female sexuality-are as heated as ever in feminist circles, academic and otherwise. And the public's fascination was aroused, in the summer of 1984 , by the story of Vanessa Williams's fall from beauty-queen grace:

1. Lisa Duggan, "Censorship in the Name of Feminism"; Richard Goldstein, "Pornography and its Discontents"; Nat Hentoff, "Is the First Amendment Dangerous to Women?" Village Voice, 16 October 1984; Susan Brownmiller et al., "The Place of Pornography: Packaging Eros for a Violent Age," Harper's, November 1984; Jean Bethke Elshtain, "Women, Politics and Pornography," The New Republic, 25 June 1984; Aric Press with Tessa Namuth et al., "The War Against Pornography: Feminists, Free Speech and the Law," Newsweek, 18 March 1985.

- 1988 by Cultural Critique. 0882-4371 (Winter 1987-88). All rights reserved. 
with the publication of pictures of a naked Williams in the September 1984 issue of Penthouse (pictures which pre-dated her ascension to the throne), the Miss America Pageant officials felt compelled to protect the good name of their venerable institution by stripping Williams of her title.

Long after the Pageant officials had airbrushed Williams out of the glorious Pageant history, casual conversation was still deciding who was more reprehensible: the Pageant officials, for adhering to hypocritical standards of decency and thereby increasing Williams's public humiliation, or Penthouse publisher Bob Guccione, for willfully creating the scandal and Williams's humiliation in order to make a fast million. In the end, only Williams lost out. The Pageant officials got a chance to reaffirm their sense of decency, to show where they draw the line; Guccione got a chance to challenge that standard of decency; and the public got something titillating to talk about and to look at-the September 1984 issue of Penthouse sold more copies than any previous installment in the magazine's fifteen-year existence. In short, for the pornography controversy, as for the pornography industry, business is booming.

This essay is about the rhetoric of pornography and anti-pornography, about the pornography controversy, but not about pornography per se. It makes no sense to speak of pornography as something that simply exists outside of a constituting discourse. Pornography is, rather, the designation of certain forms of sexual representation as beyond the pale; it is the persistent limit-case of acceptable discourse. "Pornography," in other words, is a term used by moral discourse to structure itself: wherever pornography is found to be, there the line will be drawn (provisionally) to exclude it. Vanessa Williams's story illustrates this well. Pornography per se was manifestly not the issue, but rather "pornography" was a triggering concept that allowed the Pageant officials to draw the line one place, Penthouse another, and the public according to its personal tastes. It is no accident that questions of punishmentlegal action against the officials and Guccione, whether Williams "got what she deserved"- arose in connection with this frenzy of line-drawing between acceptable and unacceptable behavior.

Williams's story is exemplary in another way as well, for it is not her story at all; it is, to revive the feminist pun, "his-story" quite completely. Guccione published the photographs without Williams's knowl- 
edge, after which the Pageant officials threatened her with action if she did not willingly resign, which she did. Guccione stripped Williams against her will, whereupon the Pageant officials, in an act of phallic one-up-manship, forced Williams to "strip" herself (of her title, yes, but we get the point). The pornographic condition of women, where the choices are outright coercion or enforced submission, is reaffirmed.

There are, then, two pornographies: the industry and the discursive term. As a practice and industry largely controlled by male interests and capital, pornography exploits women materially, requiring them, in their role as "sexual workers," to sell themselves - their bodies-as commodity objects. A materialist critique of the pornography industry, and there have been some powerful ones, would try to position the commodification of female sexuality in relation to the larger patterns of an ever-expanding exchange economy, perhaps stressing with Engels and others the role of women as the original exchange objects, perhaps seeing the massive diffusion of pornographic production as part of the expansion of mechanisms of commodification into ever more "private" realms like sexuality. ${ }^{2}$ I will not be offering such a critique, however, since my interest is in the ways in which arguments for and against pornography have tended to maintain a conflict already present in pornography itself, a conflict which is in itself satisfying: hence my focus on verbal structures and vocabularies, and the merely glancing treatment of the visual iconography of pornographic productions themselves. In other words, I will examine how the discursive structures to be found in the pornography controversy work to reinforce and maintain the pornography industry. The story of Vanessa Williams shows the mutual

2. See, for example, Frederick Engels, The Origin of the Family, Private Property, and the State (New York: International Publishers, 1942) as well as what remains, in my view, the most compelling revision and expansion of Engels's (and Lévi-Strauss's) speculations on the exchange of women, Gayle Rubin, "The Traffic in Women: Notes on the 'Political Economy' of Sex," in Toward an Anthropology of Women, ed. Rayna R. Reiter (New York: Monthly Review Press, 1975), 157-210. For a sophisticated treatment of the questions of the compatibility between feminism and Marxism that would arise in the materialist critique of pornography I have merely sketched above, see Catherine A. MacKinnon, "Feminism, Marxism, Method and the State: An Agenda for Theory," in Feminist Theory: A Critique of Ideology, ed. Nannerl O. Keohane, Michelle Z. Rosaldo, and Barbara C. Gelpi (Chicago: University of Chicago Press, 1981), 1-30. MacKinnon's article also contains a scrupulously complete bibliography (in the form of footnotes) of feminist/Marxist criticism. A more recent attempt at a Marxist analysis of pornography, in a slightly apologetic vein, can be found in Alan Soble, Pornography: Marxism, Feminism, and the Future of Sexuality (New Haven: Yale University Press, 1986). 
reinforcement of these two pornographies. This reinforcement, I will argue, is effected not so much by the diffusion of actual pornographic representations of women throughout the societal psyche, as by the replication of pornography's mode of representation. The connection between pornography and the pornography controversy, between pornography as something to look at and pornography as something to talk about and worry over, is a connection of discursive form rather than representational content.

This form is a kind of discursive agon which, in order to maintain itself (and, indeed, to reproduce itself elsewhere), depends upon a rule of exclusion. Samuel Weber has noted that the "gesture of exclusion" in certain philosophical discourses "emerges as a necessary move designed to save the agonistic process from its own tendencies towards entropy."3 This rule of exclusion, whatever its importance in philosophical discourse (some would say it is constitutive of Western metaphysics since Plato), is manifestly operative in the less exalted discourses of pornography and the pornography controversy. Pornography is a representational practice in which women, for all the graphic display of their body parts, are the excluded term. Similarly, pornography, in its guise as a self-structuring term of legal and moral discourse, is itself something of a principle of exclusion which, by continually questioning the boundaries of acceptable discourse, continually allows discourse to declare itself acceptable. What is remarkable about the discourse of and around pornography is the way in which what is excluded is simultaneously what is most desperately and obsessively represented: indeed, when more specialized vocabularies (I will be looking at legal thought, cultural critique, and psychoanalysis) turn their attention to the socio-sexual "problem" of pornography, the terms most critical to their arguments are exactly those which both conceal and display what is excluded, the hole in the theory. At all points, feminist revision of these specialized discourses will be necessary-that is, the introduction of a perspective which starts from the differential quality and descriptive effects these vocabularies have for men and women. I hope to show that pornography is necessarily a feminist concern, but not exclusively so. Exclusion, after all, is itself the issue.

3. Samuel Weber, "Texts/Contexts: Closure and Exclusion," Diacritics 10, no. 2 (Summer 1980): 37. 


\section{Legalizing Morality}

In 1957, the Supreme Court set a standard of obscenity that has proved remarkably ineffective in curbing the production, distribution, or consumption of sexually explicit material. At that time, the Court decided that a work was deemed obscene if "to the average person, applying contemporary community standards, the dominant theme of the material taken as a whole appeals to prurient interests." 4 In the same decision the Court stated that "implicit in the history of the First Amendment is the rejection of obscenity as utterly without redeeming social importance." My interest here is less the legal viability of such a standard $^{5}$ than its appeal to a set of pseudo-philosophical categories such as the "average person," "community standards," "prurient interests," and "social importance." A legal definition of obscenity would presumably try to define precisely what constitutes "prurient interests" and how these interests are to be distinguished from others of "social importance"; the standard of the Court, however, merely reasserts that there is a distinction, the felt need for which is surely the motivation behind any attempt to curb obscenity through legal action. The emphasis of the standard is on the categories of "social importance" that are ostensibly threatened by obscenity, namely the "community" and the "average person," and not at all on the nature of "prurient interests" which, in contrast to the assumed solidarity of the "average person" residing in a "community" with "standards," seem to exist in a contextual vacuum: obscene material would seem to appeal to "prurient interests" unattached to prurient people. Whatever the goal of the Court's definition, the force of its language suggests the shoring up of certain existential boundaries, of the "community" and of the self (that "average person"), beyond which floats the noxious cloud of "prurient interests." Rather than defining obscenity, the Court's standard simply reasserts the possibility of defining obscenity, a possibility assured by the assumed coherence of a community and a self able to judge.

4. Roth v. United States, 354 U.S. 476 (1957).

5. For a legal critique, see Earl Warren, “Obscenity Laws-A Shift to Reality," in The Pornography Controversy, ed. Ray C. Rist (New Brunswick: Transaction Publishers, 1975), 96-116. For an informal history of earlier obscenity laws in England and America, see H. Montgomery Hyde, A History of Pornography (London: Heinemann, 1964). 
Discouraged by the ineffectiveness of the standard, the Court, in subsequent decisions, moved away from the purely abstract definition and paid closer attention to the context surrounding the offensive action itself. Thus, in a decision of 1966 , Ginzburg $v$. United States, ${ }^{6}$ the Court found Ginzburg guilty on postal charges of obscenity. The issue was less whether his publications were themselves obscene than whether they were rendered obscene by being pandered in a commercial manner. ${ }^{7}$ The Court attempted to discern Ginzburg's obscene intent, which they did by noting that he had asked for mailing privileges in two Pennsylvania towns with the suggestive names of Intercourse and Blue Ball. The Court located Ginzburg's obscene intent in Ginzburg's own location of his obscene operation within Middle America. Whether the standard of 1957 was invoked or not, the Court reasserted the inviolability of the boundaries of the abstract "community." Ginzburg had eventually received mailing rights in Middlesex, New Jersey, but the Court could not tolerate an apparent infiltration of sex within the "community"Ginzburg's attempt to turn Middle America into Middlesex, America.

The Court's categories of "community standards" and the "average person" have, in fact, proved as tenacious as pornographers' ingenuity in escaping obscenity restrictions. In 1970, the Commission on Obscenity and Pornography, a research group set up by President Johnson in 1967 in response to apparent public concern over the issue, published its findings. They discovered no evidence that exposure to pornography led to an increase in anti-social behavior, and recommended the appeal of most existing legislation restricting sexually explicit material. ${ }^{8}$ The Nixon administration immediately dissociated itself from the report, and the Court, soon afterwards, made explicit its disregard for what might pass as empirical evidence. Chief Justice Warren Burger wrote in 1973: "Although there is no conclusive proof between antisocial behavior and obscene materials, the legislature of Georgia could quite reasonably assume that such a connection does or might exist."9 In other words, the legislature of Georgia can assume

6. 383 U.S. 463 (1966).

7. The facts of the case can be found in Warren, "Obscenity Laws," and in John H. Gagnon and William Simon, "Pornography-Raging Menace or Paper Tiger?" in The Pornography Controversy, 85-95.

8. For details, see Ray C. Rist, "Pornography as a Social Problem," in The Pornography Controversy, 1-15.

9. Cited in Rist, Ibid., 7. 
"community standards," and can act to protect those standards from the nefarious influence of obscene materials; the nefarious influence can itself be assumed. Whether or not the Court or the legislature of Georgia should have the power to disregard the absence of "conclusive proof' is not my concern. What is important is the open expression of the Court's role as not simply limiting, but constructing as well. This assertive power of the Court lies less in the creation of a definition of obscenity than in the reiterated assumption of categories of being, the unitary self and the united body politic. The invocation of these categories is also in part their creation, and this invocation allows the Court to state, repeatedly, little more than that there is a conflict between two separable entities, "prurient interests" and "community standards." But if "prurient interests" do not exist outside of context, if in fact they reside within the "community" or even within the "average person," attempts to limit those interests by assuming their exteriority will necessarily fail. The massive pornography industry is evidence that such attempts have failed. And yet the conflict continues, for it is the very representation of conflict that is reassuring to the self and to society, reassuring precisely because such a representation assumes that the self and society can stand solid and unitary against their own internal divisions.

The most crucial societal division glossed over in the Supreme Court's treatment of obscenity is that of gender. The dialectic described above, in which abstract definitions of obscenity, by their very unenforcability, allow for more production of pornography, which in turn provides more opportunities for the Court to assert the existence of an undivided self and polity, is a male dialectic, self-enclosed and self-regenerating. Almost without exception, the courts are male, the pornographers are male, and the prurient interests (the consumers of pornography) are male. The "average person" and the "community" which the Court assumes, and which are in fact self-divided by "prurient interests," are male. In other words, the Court handles pornography (their word is "obscenity") as a discursive term without specific implications for gender relations. They do not, at base, consider pornography as a practice with effects and significations that are genderspecific.

In 1983, Catherine MacKinnon and Andrea Dworkin presented to 
the City Council of Minneapolis a legislative ordinance that considers pornography precisely as a practice, a discriminatory one. In the words of the ordinance: "The Council finds that pornography is central in creating and maintaining the civil inequality of the sexes." 10 Abstract notions of obscenity become irrelevant when pornography is thus conceived as a discriminatory practice which constitutes an infringement of the civil rights of women. The ordinance passed the City Council but was vetoed (twice) by the mayor of Minneapolis. In 1984, another version of the ordinance was passed by the mayor of Indianapolis, only to be struck down by the courts in November of that year as unconstitutional. ${ }^{11}$ Many other cities have found the re-interpretation of pornography offered by MacKinnon and Dworkin very appealing as a possible means of legal action.

The ordinance correctly understands that a public representation is not politically or ideologically innocent, but itself constitutes an act. The difficulty, however, lies in negotiating the connection between the content of the representation and the action that is the public display of that representation. An image of violence against women, displayed publicly, does constitute a form of violence against women, but not the same violence as that depicted in the image. The difference between the two is precisely what is elided by the language of the "Special Findings" section of the ordinance: "Pornography is a systematic practice of exploitation and subordination based on sex which differentially harms women. The bigotry and contempt it promotes, with the acts of aggression it fosters, harm women's opportunities for equality of rights ..."(Appendix II, 206). In the first sentence, "practice" could well refer to the interior workings of the pornography industry itself, in which women (those who work as models, actresses, etc.) are systematically exploited by, and subordinate to, the male producers and entrepreneurs in control of the industry. As the second sentence makes clear, however, "practice" in fact refers to the dissemination of pornography, its impact on the public: pornography, as the representation of exploited and subordinated women, reproduces itself in the public sphere, promoting bigotry and fostering violence. What happens to women

10. Excerpts from the Minneapolis ordinance can be found as "Appendix II" in Women Against Censorship, ed. Varda Burstyn (Vancouver: Douglas and McIntyre, 1985), 206-8.

11. For details of the Indianapolis story, see Lisa Duggan, "Censorship in the Name of Feminism." 
within the pornography industry happens to all women outside. The medium for this exchange of exploitation, bigotry, contempt, and aggression is, precisely, the public representation of it.

The issue, then, is the relation between discourses, specifically the relation between the specialized discourse of the pornography industry (which uses a limited set of iconographic images and textual techniques to represent the "sexually explicit subordination of women" [Appendix II, 206]) and the general discourse of society (which also subordinates women, but in many spheres other than the sexual, and with different, often more insidious techniques). The Minneapolis ordinance conceives this relation causally: "Pornography is central in creating and maintaining the civil inequality of the sexes" (my emphasis). Pornography is, therefore, the temporally and logically prior locus of the oppression of women from which emanate the manifestations of sex discrimination in all spheres of civil society; the manner in which pornographic representation transmits sexist ideology is not considered problematic. ${ }^{12}$

Pornography is central, for MacKinnon and Dworkin, because sexuality is central. The societal subordination of women is dependent upon, and grows out of, the sexual subordination of women. Hence pornography, as the purest expression of that sexual subordination, is responsible for "creating," at the societal level, the economic, legal, and intellectual oppression of women. But if pornography represents female sexuality as victimization, what notion of female sexuality do MacKinnon and Dworkin entertain? Obviously, an ordinance against pornography is not the vehicle for an elaboration of the nature of female sexuality. Nevertheless, as Carole Vance has noted, ${ }^{13}$ the ordinance, in the name of protecting women against the all-too-common attacks of complicity (an attack consistently made in rape trials), altogether discounts the very notion of female sexual consent.

12. The ordinance does consider pornographic imagery in some detail, but here, too, there is slippage between discursive spheres. Words that connote women's experience in (sexist) society, such as "subordination," "humiliation," and "inferior," are nestled in with words which properly describe pornographic violence. That this slippage is part of the relation between pornography and society is doubtless true, but it is important to understand the nature of this slippage, not simply take the terminological confusion for granted.

13. See Lisa Duggan, Nan Hunter, and Carole S. Vance, "False Promises: Antipornography Legislation in the U.S.," in Women Against Censorship, 130-51. 
Section M of the Minneapolis ordinance reads: "Any person, including transsexual, who is coerced, intimidated, or fraudulently induced ... into performing for pornography, shall have a cause of action . . ." (Appendix II, 207). There follows a list of "facts or conditions" which "shall not, without more, negate a finding of coercion." These include conditions used regularly by rape lawyers to impute complicity on the part of the victim: that the victim is a woman (aa), a prostitute (bb), of the age of majority (cc), or is related to the defendant (dd). Other conditions, however, which shall not "negate a finding of coercion" in fact negate the notion of consent: "that the person actually consented to a use of the performance that is changed into pornography" (hh); "that the person showed no resistance or appeared to co-operate actively" (ij); "that the person signed a contract, or made statements affirming a willingness to co-operate in the production of pornography" (kk); that no force was used, or that the person was paid (ll, $\mathrm{mm}$ )(Appendix II, 207-8). In repudiating the validity of consent, these conditions assert that pornography simply is coercion.

In this respect, the Minneapolis ordinance takes the extreme expressions of pornography, in which women are pictured bound, tortured, or raped, at their word: women's relation to male sexuality is, as Hustler would have it, one of utter victimization. Any expression of female consent (from a porn star, for example, who claims to enjoy her profession) is discounted as meaningless, at least in terms of defense. Whether stigmatized by society as morally depraved, or discounted by the Minneapolis ordinance as victimized and hence without any meaningful language of consent, the female sexual worker (model, porn actress, prostitute) receives the same treatment: enforced silence and marginalization. Moreover, because the ordinance understands pornography as the source of the (successfully) coercive ideology of sexism, women who do not work in sex industries, and yet who have ambivalent or even positive relationships to the dominant sexual arrangements, are similarly suspect: the greater your involvement, the more complete your coercion, the less you can know what you want.

The Supreme Court's efforts to curb pornography failed because it refused to recognize the self-divided nature of the (male) public it was trying to protect: the Court failed to understand that "prurient interests" could not be placed in an exterior position to the "community" and the "average person" simply by legislative fiat. As we have seen, however, 
there is a psychological payoff in this very failure. The Minneapolis ordinance repeats the failure for a female public: by discounting any notion of female consent to pornography and hence to general sexual arrangements, the ordinance ignores the self-divided nature of female sexuality in favor of a purer vision of gender-defined conflict. Unfortunately, the psychological payoff is not commensurate for women. For, while male assertions of a unitary self do not prohibit continued expressions of male sexuality (witness the huge pornography industry), the denial of female sexual ambivalence, of even partial consent to present sexual arrangements, merely continues the silencing of female sexual expression that society already enforces. ${ }^{14}$

The Supreme Court understood pornography as lying at the fringes of society; the Minneapolis ordinance understands it as lying at the heart of society, "central." The Supreme Court considered pornography abstractly, as a discursive term ("obscenity") that stood in opposition to a male self and polity; it did not consider the way in which pornography is also a practice. The Minneapolis ordinance considers pornography purely as practice, and then proceeds to conflate that practice with discourse itself. Both legal approaches place men at the center (either the unitary male untainted with "prurient interests," or the rapacious pornographer emanating sexist ideology); both approaches marginalize women (either by ignoring them, or by portraying them as pure victims, coerced by discourse itself). Perhaps the two conceptions can be pictured as follows:

\section{The Circle of Male Discourse}

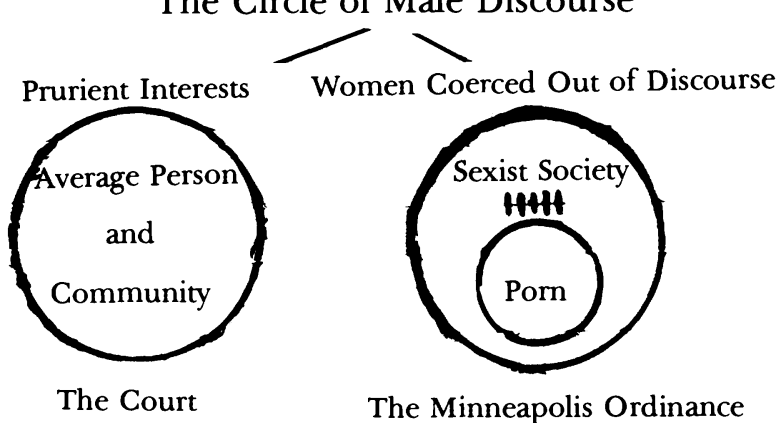

14. Some feminists have long been calling for the diversion of attention away from male abuses, understood as crippling of an authentic female sexuality, and onto the affirmation and construction of a genuine female sexual expression. For an anthology that makes this appeal, see Pleasure and Danger: Exploring Female Sexuality, ed. Carole 
The Supreme Court, ignoring pornography's differential effect on women, effectively relegates them to the fringes of male discourse, as speechless as the dirty pictures of the "prurient interests." MacKinnon and Dworkin, radically discounting the notion of female consent while simultaneously conflating the coercive discourse of pornography with the general discourse of society, also relegate women to a position at the fringe, powerless to assert a female sexuality, as speechless as obscene photographs.

The Supreme Court and the Minneapolis ordinance locate pornography differently, as fringe or as center, and yet the structure remains the same: a circle of male discourse exclusive of women. Perhaps attempts to legislate pornography necessarily reproduce this rule of exclusion; perhaps attempts to legalize morality necessarily obscure and conflate the intricate relations between sexuality, representation, and discourse as these relations play themselves out differently for men and women. Is this the lesson to be learned from the apparent appropriation of the feminist anti-pornography movement by the New Right? ${ }^{15}$

"I know it when I see it," said Justice Stewart. The question remains whether we can know it before we can see it. I will now turn to other attempts to see it, attempts not bound by the peculiarly intransigent rhetoric of the law. Perhaps speaking about pornography differently changes what it looks like.

\section{The Culture of Pornography}

I am a pornographer. My magazines are raunchier, more disgusting, more lewd, licentious and vile than anything on the market. They don't need to have any social redeeming importance other than what they have: to illustrate graphically that our nation is hung up on sex, a natural function of healthy primates that has been suppressed because of religion.

- Larry Flynt, Propaganda flyer

Pornographers generally consider themselves champions of freedom of speech, and as such tend to ally themselves with the political

Vance (London: Routledge and Kegan Paul, 1984), especially the essays by Vance, Gayle Rubin, Alice Echols, and Paula Webster.

15. See Duggan, "Censorship in the Name of Feminism." 
left. ${ }^{16}$ Larry Flynt certainly does: he was the defendant in a $\$ 45$ million libel suit lodged by the Great Right Hope himself, the Reverend Jerry Falwell. The flyer from which the above passage is taken reads like a catalogue of leftist rhetoric. Flynt's argument hinges on the hypocrisy of the notion of permissible and impermissible freedoms of speech. Those whose expression was considered impermissible are the heroes of progressives: Dred Scott, Susan B. Anthony, Margaret Sanger, the NAACP, Dennis Banks, Thomas Paine; those whose expressions were permissible are villains: the Ku Klux Klan, Attorney General Palmer, Comstock, McCarthy, "Father" Terminiello. One need not be a libertarian to find Flynt's list compelling.

Is Flynt's leftist rhetoric merely a smoke-screen, what Lewis Lapham calls the "pretense to political statement,"17 or is there a genuine relation between pornography as a practice and the rhetoric of its apologists? In the passage cited above, Flynt seems to feel that pornography's existence is its own apology: the social importance of his magazines simply is that they "illustrate that our nation is hung up on sex." The word "illustrate" has a curious double meaning here. It could refer to the images in Flynt's magazines, in which case it seems fair to say that it is Flynt's enterprise that is "hung up on sex." On the other hand, Flynt must also conceive of his enterprise as already ensconced in its public role. In this sense, the existence of Hustler "illustrates" that "our nation is hung up on sex" in two ways: by its sales, which indicate an audience, and by the virulent opposition it arouses, which indicates another audience "hung up on sex." Flynt's enterprise, then, is both fringe and mainstream: its libertarian polemic is both sustained and justified by its secure position in the mainstream market economy. Al Goldstein, publisher of Screw magazine, agrees with Flynt: pornography "serves as a visual polemic that encourages people to feel more open about their sexuality. In the pages of Screw, and in pornography in general, a philosophic argument is being set out that is intended to liberate people sexually." 18 Screw is a weekly tabloid that eschews mainstream pornographic iconography in favor of sexual and political (leftist, of course) polemic. The polemic comprises

16. For histories of various pornographers and their political affiliations in former times, see Hyde, A History of Pormography.

17. In "The Place of Pornography," Harper's, November 1984.

18. Ibid. 
half the normal issue; the other half is purely economic-pictorial advertisements for paraphernalia, literature, and prostitutes-male, female, and transsexual.

For Goldstein and Flynt, the "visual polemic" of pornography is inextricably linked to economics: they champion the right to sell sexuality as everything else is sold in our society. Hugh Hefner, the daddy of American pornographers, understood this well. From its opening issue, Playboy could afford to mute its polemic because it presented itself as already ensconced in the secure economic sphere of the upper class:

Most of today's "magazines for men" spend all their time out-ofdoors-thrashing through thorny thickets or splashing about in fast-flowing streams. We'll be out there too, occasionally, but we don't mind telling you in advance- we plan on spending most of our time inside. We like our apartment. We enjoy mixing up cocktails and an hors d'oeuvre or two, putting a little mood music on the phonograph, and inviting a female acquaintance for a quiet discussion on Picasso, Nietzsche, jazz, sex. ${ }^{19}$

Playboy's polemic is surely mild: no ranting about America's sexual hangups, just a polite jab at other "men's magazines." Sex seems peripheral to the main goal, the enjoyment of the good life. Indeed, sex is just another aspect of high culture, side by side with Picasso and Nietzsche. Let Flynt and Goldstein "thrash through the thorny thickets" of the world of hard-core pornography, we can join Hef in his cozy apartment, or rather his numerous mansions.

Evidently, pornography makes good business sense. The pornography industry is well entrenched in the market economy. Why, then, do renegade pornographers like Flynt and Goldstein consistently make trouble? Why don't they learn from business moguls like Hefner and Guccione and clean up their product in search of ever larger profits?

By consistently challenging the limits to acceptable speech, hardcore pornographers get a sense of mission while still making good money. This mission can seem political, as with Flynt's list of history's heroes who challenged the past limits of expression, or it can seem

19. Quoted in Peter Michelson, "The Pleasures of Commodity, or How to Make the World Safe for Pornography," in The Pornography Controversy, 143, 145. 
religious, as when Flynt sets his message of sexual liberation in opposition to "religion," which has "suppressed" the "natural function of healthy primates." 20 This campaign against religion, however, poses no real threat since it is completely contained within a self-generating dialectic of morality. Pornography, in its political and religious guises, is once again nothing more than a discursive term which, as the apparently opposite face of morality, assures the continued existence of an overarching moral discourse. Moral indignation which expresses itself as legislation will fail precisely because it is in its interest to do so. The Supreme Court and the "immoral" pornographers need each other: by constantly rehearsing the conflict, each assures the other of continued existence. They are mirror images which reflect and perpetuate the systematic moral discourse which contains them. Both Jerry Falwell and Larry Flynt are, after all, "born again."

The political and/or religious mission of pornography is a ruse: it is the very sense of mission which affords the psychological payoff. In considering the Supreme Court's stand regarding obscenity, I suggested that the consistent appeal to categories of being like the "average person" was a shoring up of existential boundaries that was in itself gratifying. In turning now to the Court's other half, those champions of free speech and sexual liberation, we can find, in their more colorful rhetoric, the specifically erotic component in this psychological gratification.

In 1968, Charles Rembar, the lawyer who defended Fanny Hill, Tropic of Cancer, and Lady Chatterly's Lover against obscenity charges, published a book about the trials entitled The End of Obscenity. ${ }^{21}$ Norman Mailer, Rembar's cousin, wrote the introduction. In a few overexerted pages, Mailer manages to draw together the various strands that compose the psychic economy of those rebels that challenge the limits on free speech. The prevailing mood is martial. Mailer speaks of the "legal revolution led by a few determined and extraordinary publishers," who remind him of certain "Civil War Generals" (v). From there, Mailer waxes nostalgic for his youth, when Cy Rembar, eight years his

20. This anti-religious campaign of de-mystification has a long and respected tradition, dating back at least to Sade's famous harangue, "Yet another Effort, Frenchmen, if you would become Republicans," in Philosophy in the Bedroom (New York: Grove Press, 1965).

21. Charles Rembar, The End of Obscenity (New York: Bantam, 1968). 
senior, served as something of an older brother to him. Rembar was, according to Mailer, extraordinarily good with the bat, regularly hitting late-inning homers. Rembar's baseball prowess is intimately connected with his abilities as a lawyer in Mailer's mind, and both are subsumed in a sexual economy: even today, Mailer cries, Rembar "looks for moral issues in his activities. And still plays baseball. And still might take a girl away from me if he chose to" (vii). For Mailer, if you're good with the bat, you're good with the girls, and you're good with "moral issues" like challenging obscenity laws. The focus grows sharper: Mailer tells us that Rembar's "particular ability . . . to reason has become a force which approaches the power of a mighty muscle" (vii). And in a final phallic salute, Mailer welcomes Rembar into the elite circle of writers and thinkers at the cutting edge of penetrating moral insight: "Welcome to my racket, Cousin Cy, Gentleman Sword" (ix). The nexus of power, force, and reason, so dear to the mind committed to phallic mastery, could not be clearer; nor could the imaged weapon, whether it be baseball bat, sword, or even the "mighty muscle" itself.

It is not surprising that the rhetoric in the controversy over pornography should be riddled with sexual anxiety or, as with Mailer, phallic crowing. What is surprising is that it would ever be considered as anything other than a sexual dilemma. The obfuscations of the Supreme Court are perhaps indicative of male sexual anxiety ill at ease with its internal "prurient interests," while stout souls like Mailer are manifestly cocksure. Like the Supreme Court, the apologists for pornography conceive their mission in relation to a male public; the clamor of the debate, a debate which we now see is intimately related to male sexuality, takes place around a silent central hole. Female sexuality is that hole. The entire male debate depends upon that silent sexuality; those speechless dirty pictures are, quite literally, the hole in the male argument.

Male sexuality's need for this enforced silence has, indeed, been the focus of much feminist critique of pornography. ${ }^{22}$ This would seem to be the place for another of the promised feminist revisions: like the Minneapolis ordinance, the feminist critique could re-emphasize the

22. See, for example, Susan Griffin, Pornography and Silence (New York: Harper and Row, 1981) and Andrea Dworkin, Pornography: Men Possessing Women (New York: Perigree Books, 1979). 
consequences of pornography as practice. Perhaps a feminist cultural critique could even make female sexuality speak more openly than the Minneapolis ordinance. I would like, however, to pursue a different tack. Mailer's rhetoric glaringly reveals the figures of male sexuality which underlie the male debate over sexually explicit material. His language suggests that the real debate may not be political, legal, or religious at all, but that the real battlefield may be the psyche. We can expect by now that the psyche considered will be male. And yet, in pursuing the attempts to understand pornography as a psychic phenomenon, we may reach fundamental ground, and a place from which female sexuality can speak too.

"In discussing censorship, it is impossible to make good sense and good law without sociological psychological analysis." So writes Paul Goodman in his influential essay of 1961, "Pornography, Art and Censorship." ${ }^{23}$ Goodman's essay is one of the more subtle attempts to treat pornography and censorship as expressions of a collective societal psyche: it is in this sense that his analysis is simultaneously "sociological" and "psychological." Goodman's central question is "what if censorship itself, part of a general repressive antisexuality, causes the evil, creates the need for a sadistic pornography sold at a criminal profit?" (43). Goodman understands that there are psychic motives behind social legislation, but he sees only half of the process, which is not causative but dialectical. He understands that "censoring is a dynamic and emotional act," but then says: "The social question is not the freedom of a venal purveyor, though the case is always argued in his terms since he is the one brought to court; the question is whether the sexual climate of the community is being perverted by the censorship" (42). Like the Minneapolis ordinance, Goodman realizes that the "social problem" is not limited to questions of free speech, but is the result of a certain social practice. This practice, however, makes all the difference: where the Minneapolis ordinance would place "pornography" Goodman places "censorship."

In the end, Goodman fails in precisely what he sets out to do, namely, to fuse sociological and psychological analyses. Speaking of sadomasochistic pornography, that which "combines lust and punishment,

23. Paul Goodman, "Pornography, Art and Censorship," in Perspectives on Pornography, ed. Douglas A. Hughes (New York: St. Martin's Press, 1970), 43. 
torture and humiliation," Goodman writes: "For the consumer, such fantasies have a dual advantage: they satisfy both the need for righteousness (sadistic superego) and the 'weakness' of giving in to pleasure; they embody an exciting conflict" (56). As far as it goes, this seems an accurate appraisal of the psychology of sado-masochistic fantasies. Yet Goodman misses the sociological validity of his analysis: "But the bother with such images when used privately as pornography is that they are socially disapproved and enhance individual guilt; the excitement proceeds against strong resistance, and mounting fear, and often dies; and there is a tendency to raise the ante" (56-57). It is hard to see how, if the "excitement often dies," there is also a "tendency to raise the ante." Raising the ante precisely is the excitement, the assurance that the game will continue. Goodman's individual consumer delights in the "exciting conflict" between righteousness and weakness; why shouldn't general "social disapproval" (in the form of censorship laws) act as the "sadistic superego" just as well as whatever figure of righteousness appears in the pornographic fantasies themselves? Goodman's psychological understanding of the dialectic of lust and punishment fails him at the sociological level, where it is in fact replayed by the good guys (the courts) and the bad guys (the pornographers); the consumer finds himself in the middle of an "exciting conflict." It is in this way that pornography extends its sway throughout mainstream society: through the repetition not of the pornographic content, but of pornography's form: the exciting conflict. This repetition marks the passage from pornography as practice to pornography as discourse.

Underlying Goodman's analysis of pornography and censorship is a half-hearted Freudianism: his attack on repressive morality (in legislation or religious dogma) is one of the clearest examples of what has come to be known as the "cathartic theory," the idea that pornography serves as a release for various sexual anxieties and drives (male drives, to be sure, though Goodman does not mention this). I quote the following passage to demonstrate the curious obfuscations his argument entails:

The fact is that our generations are living through a general breakdown of repressive defenses, increasingly accelerated; and therefore a deepening social neurosis. Freud's doctrine, let us remember, is that it is not repression (total amnesia) that causes neurosis, but the failure of repression, so that the repressed contents return 
in distorted guise. The process is irreversible; our culture has experienced too much of it to ban it, or frighten it, out of mind. Therefore, the only recourse is to try to get, as methodically as possible, to the end of it, so that the drives can reappear as themselves and come to their own equilibrium. This involves undoing the repressive attitude itself. (47-48)

What is odd about this passage is that it first indicts repression for not doing a good enough job, and then calls for the "undoing" of the "repressive attitude itself." But what, exactly, does Goodman suggest is being repressed? All we hear is that "our culture has experienced too much of it," we cannot "ban it" or "frighten it," we must merely try to get to the "end of it." What is "it"? Pornography? (You can't really "frighten" pornography). Repression? Sex? (Can one come to the end of sex?) "It" just is, and you can't know "it" till you see "it." Goodman's analysis performs the very failed repression it criticizes, for, while we do not really know "it," it is hard to believe that there is no "it."

Let us assume, for the moment, that this unspoken entity, this "it," is exactly what has never yet been faced squarely in this debate, nor yet in this paper: sexuality. What remains unclear about this sexuality is whether "it" is male or female, or whether "it" is the relation between the two. Susan Griffin, criticizing the "cathartic theory," captures the double-edged nature of arguments like Goodman's:

Underneath the argument that pornography is cathartic . . is a terrible nostalgia and a grief from the imagined loss of this primal violence. And so the double message. The speaker who utters opposite truths out of each side of his mouth. The Janus head. Gemini. I do not believe what this head is saying to me. In the first place, the head is severed. And it is not Salome who holds it up for admiration. The head has detached itself from the body and blames the body for its own beastliness. ${ }^{24}$

Goodman, who just wants to get to the "end of it," but yet cannot bring himself to name "it," would seem to be Griffin's speaker who "utters opposite truths out of each side of his mouth." Griffin sees this

24. Griffin, "Sadism and Catharsis: The Treatment Is the Disease," in Take Back the Night: Women on Pornography, ed. Laura Lederer (New York: William Morrow and Co., 1980), 143. 
double message as the mark of an interior conflict ("the twin love of violence and fear of violence" [143]) that has been falsely exteriorized: what is purely internal to the intellect is seen as a mind-body conflict by the mind bent on preserving the conflict. It is this will to maintain the conflict that lies at the heart of the male debate over pornography. It is what makes all the putative rivals come to resemble each other, so that Jerry Falwell and Larry Flynt appear as mirror images, Gemini.

There is a suggestive power in Griffin's language unmatched by any of the male critics considered thus far. The mixture of fascination and fear, what Griffin suggests lies at the heart of the pornography controversy, is itself evoked in the violence of her central image: the severed head blaming the body for its own beastliness. The image is a distillation of an entire network of sexually symbolic motives centering on the fear of castration. Salome is mentioned, but it is Medusa's head which underlies the image. It is a measure of Griffin's acumen, however, that Medusa is nowhere to be found: the castration scenario is an exclusively male drama. Perhaps pornography's incessant display of female genitals, like the myth of Perseus and Medusa, is nothing more than a pretext for the continued generation of this drama. Perhaps, as Griffin suggests, Perseus castrates himself so that the ultimate fetish object, that terrifying talking head, can chatter on, continually re-making its fetishized discourse.

Goodman's account of the cathartic theory, and Griffin's critique of it, seem to have propelled us into what comes to look more and more like a psychoanalytic vocabulary. I would like now to turn to the psychoanalysts themselves in order to discover what such terms as castration and fetishism might mean in relation to the pornography controversy, as well as what significance such concepts might have for the problem of representation that we have run up against in every effort to talk about pornography - the problem, that is, of the limits of discourse.

\section{The Psychoanalytic Fetish}

It is always in relation to the question of representation, to the way in which the subject is constructed by and in language, that psychoanalysis, or at least the strain of psychoanalytic speculation that I will be considering here, orders its inquiry. In the second series of lectures 
included in The Four Fundamental Concepts of Psychoanalysis, Jacques Lacan approaches this problem in terms peculiarly appropriate to the interests of this essay, for it is in those lectures that he focuses on the function of the scopic drive (the pleasure in looking) in the register of desire. Lacan attempts to understand this drive by asking, "Must we not distinguish between the function of the eye and that of the gaze?" 25 The force of this distinction lies in the fact that what is seen by the eye is not, for Lacan, simply out there, but must first be constituted as something seeable: there is a "pre-existence to the seen of a given-tobe-seen" (74). This pre-existent, that which gives to be seen, Lacan calls the gaze, "which always escapes from that form of vision that is satisfied with itself in imagining itself as consciousness" (74). The gaze, then, is constitutive of "that form of vision" which is the function of the eye, namely consciousness; and like the unconscious, which constitutes the basis and reserve from which consciousness arises, the gaze always remains just out of sight.

Lacan is explicit about the connection between the "given-to-beseen" and consciousness: we are not simply conscious beings who direct our eye to various objects; we are first of all "beings who are looked at, in the spectacle of the world. That which makes us consciousness institutes us by the same token as speculum mundi" (75, my emphasis). In this way, the split between the eye and the gaze would seem to introduce a wild reciprocity into the scopic field itself, wherein "The spectacle of the world . . . appears to us as all-seeing" (75). As it happens, however, this speculum mundi in which all that is seen is simultaneously "all-seeing" does not necessarily mark the presence (or intervention) of the gaze. Lacan makes that intervention depend upon a certain form of exhibitionism: "The world is all-seeing, but it is not exhibitionistic-it does not provoke our gaze. When it begins to provoke it, the feeling of strangeness begins too" (75). This provocation is fundamentally an unconscious operation, since in consciousness, "in the so-called waking state, there is an elision of the gaze, and an elision of the fact that not only does it look, it also shows. In the field of the dream, on the other hand what characterizes the images is the it shows" (75).

We are back, once again, to "it" and, I suspect, in the field of sexuality's

25. Jacques Lacan, The Four Fundamental Concepts of Psychoanalysis, ed. Jacques-Alain Miller, tr. Alan Sheridan (New York: W. W. Norton, 1978), 74. 
relation to representation. Lacan's dream-images mark the intervention of the gaze by their exhibitionistic intensity-and in this way, they come to resemble pornography, which would above all like us to believe that "it shows":

It shows-but here, too, some form of sliding away of the subject is apparent. Look up some description of a dream, any one-... place it in its co-ordinates, and you will see that this it shows is well to the fore. So much is it to the fore, with the characteristics in which it is co-ordinated-namely, the absence of horizon, the enclosure, of that which is contemplated in the waking state, and, also, the character of emergence, of contrast, of stain, of its images, the intensification of their colours-that, in the final resort, our position in the dream is profoundly that of someone who does not see. The subject does not see where it is leading, he follows. (75)

Whatever the nature of these dream images that show, Lacan's dreamexperience seems, at times, distinctly like a pornographic experience: the lack of a sense of containment or "enclosure" so that the entire field of concentration is centered on the image; the lurid "intensification" of the images themselves; the profound encounter with "contrast" and the sense of a spreading "stain" or guilt; and most importantly, the absolute coercion of the subject: "he does not see where it is leading, he follows." In his next lecture, entitled "Anamorphosis," Lacan discusses the intervention of the gaze in terms even more reminiscent of the pornographic experience. He refers us to Sartre's famous discussion in Being and Nothingness, where, as Lacan notes,

far from speaking of the emergence of this gaze as of something that concerns the organ of sight, [Sartre] refers to the sound of rustling leaves, ... to a footstep heard in a corridor. And when are these sounds heard? At the moment when he has presented himself in the action of looking through a keyhole. A gaze surprises him in the function of voyeur . . . Is it not clear that the gaze intervenes here only in as much as it is not the annihilating subject, correlative of the world of objectivity, who feels himself surprised, but the subject sustaining himself in a function of desire? (84-85) 
Given such examples of the intervention of the gaze which gives to be seen, which shows, it is perhaps not very surprising that Lacan connects such an intervention with a feminine operation: "At the very level of the phenomenal experience of contemplation, this all-seeing aspect is to be found in the satisfaction of a woman who knows that she is being looked at, on condition that one does not show her that one knows that she knows" (75).

In this last sentence, Lacan does little more than describe the classic pornographic contract: the woman gives herself to be looked at, provided the look is anonymous or furtive. Her satisfaction derives not from direct sight, but from the privileged displacement of the gaze, from the place of the Other: she watches the pleasure of others watching her, who by contract, do not acknowledge her vision of their pleasure. Lacan's emphasis in this structure is on the woman's "satisfaction" and her prior seeing. The remarkable thing in pornographic images would be, for Lacan, not what female genitalia look like, but the way they look. As he remarks cryptically to his audience: "You no doubt eat oysters, innocently enough, without knowing that at this level in the animal kingdom the eye has already appeared" (91). For the furtive consumer of pornography, not only do the walls have eyes, the images being consumed (huitre, oyster, is French slang for vagina) are looking at him themselves. ${ }^{26}$

Lacan's emphasis on the woman's "satisfaction" in giving herself to be seen is not at all unusual; indeed, the pornographers themselves have made the depiction (or simulation) of female pleasure one of their central concerns, quite without the help of Lacan. John Ellis has discussed the pornographic portrayal of women's sexual pleasure as just another fetish in the "fetishistic regime" of pornography: "Besides the massive diffusion of vaginal imagery ... (imagery often described as explicit or aggressive), there also appears a concentration on lesbian activities ... and upon female masturbation, where it is often implied strongly by various poses." 27 Ellis suggests that female self-pleasuring functions just like any other fetish object, i.e., as a disavowal of the fact

26. Once one makes the connection between Lacan's notion of the gaze and its peculiar connection to a feminine identity, it is difficult to avoid a certain pornographic understanding of a sentence like the following in which Lacan describes "the gaze as such, in its pulsatile, dazzling and spread out function" (89).

27. John Ellis, "Photography/Pornography/Art/Pornography," Screen 21, no. 1 (Spring 1980): 102. 
of castration. Following Lacan's revision of Freud, Ellis understands castration as loss of the phallus, and not of any real organ, like the penis. ${ }^{28}$ As is often the case, this distinction is extremely hard to maintain. Ellis claims that, even in scenes of female masturbation or lesbianism, the phallus is posited as the necessary item: "the fetishistic regime is maintained by the re-assertion of the phallus as the possession of the male, and the female as dependent on the phallus as access to pleasure. The male spectator is sutured into the representation as the possessor of the pre-requisite; and thus confirmed in a particular psycho-social construction of self' (105). But the phallus belongs to no one, as Lacan makes clear; evidently the "pre-requisite" possessed by the male is what he has and the woman doesn't, namely the penis. In the passage above, it is difficult to tell who is more deluded: the male spectator convinced that he has the phallus, or Ellis himself, who thinks the male spectator thinks he has the phallus and not the penis. ${ }^{29}$

Freud, in his short essay on fetishism, is less obfuscatory: "The normal prototype of all fetishes is the penis of the man, just as the normal prototype of an organ felt to be inferior is the real little penis of the woman, the clitoris." ${ }^{30}$ According to Freud, objects become fetishes when "interest is held up at a certain point-what is possibly the last impression received before the uncanny traumatic one is preserved as a fetish" (217). Thus the foot or shoe are common fetishes due to the "circumstance that the inquisitive boy used to peer up the woman's legs toward her genitals" (217). As so often with Freud, the scenario is narrativized: the little boy looks up the woman's dress, only to find . . . nothing! So the "last impression received" becomes the fetish, because "interest is held up at a certain point." Whose interest? Surely not the little boy's: his interest was clearly piqued, and he went all the way-he would not need a fetish object to deny the woman's castration if he had stopped at the shoe.

It is, I think, Freud's "interest" that is "held up at a certain point."

28. Ellis, in fact, borrows his terminology almost directly from Lacan's discussion of the gaze, which is why he can say "the woman's gaze is where her phallus is located" (101).

29. For a good exposition of the difficulty of keeping the two terms apart, see Jane Gallop, The Daughter's Seduction: Feminism and Psychoanalysis (Ithaca: Cornell University Press, 1982), $94 \mathrm{ff}$.

30. Sigmund Freud, "Fetishism," in Sexuality and the Psychology of Love, ed. Philip Rieff (New York: Collier Books, 1963), 219. 
Freud's little narrative of investigation and revelation is rather thrilling. So thrilling, in fact, that he repeats it for the reader in his own analysis. I quote the text in full to preserve the suspense:

In all cases the meaning and purpose of the fetish turned out under analysis to be the same. It revealed itself so unequivocally and seemed to me so categorical that I should expect the same solution in all cases of fetishism. When I now disclose that the fetish is a penis-substitute, I shall certainly arouse disappointment; so I hasten to add that it is not a substitute for any chance penis, but for a particular quite special penis that had been extremely important in early childhood but was afterwards lost. That is to say: it should have been given up, but the purpose of the fetish precisely is to preserve it from being lost. To put it plainly: the fetish is a substitute for the woman's (mother's) phallus which the little boy once believed in and does not wish to forgo-we know why. (214-15)

Freud's language is almost flirtatiously coy here. He has seen what there is to see- "it revealed itself" to him "unequivocally"-and he will now reveal the same to us with a flourish: "When I now disclose" .. . what? A "penis-substitute!" We are "disappointed," yet "aroused" by that very disappointment. But there is more excitement still, for this fetish is not a substitute for "any chance penis" (whatever that is), but for (here the redundancy is crucial) a "particular quite special penis"the mother's. Just when Freud had us looking up mother's dress, his "interest" is "held up," and we get, as so many times before, the same old penis, to which everything, no matter how exciting, always returns. Freud is certain of his audience- "we know why." As Ellis writes of the pornographic experience: "all that can be shown in a film or a photograph is the conditions of pleasure, its circumstances and outward manifestations ... all that the viewer finds as the reply to the question are the outward displays, what is expected" (105). The penis (or the phallus, if you are a Lacanian) is, we are constantly reassured, the "conditions of pleasure"-in bed as in theory. We know why.

Lacan, even more than Freud, plays hide-and-seek with his reader, delays pleasure through the extended foreplay of his theory. Nevertheless, we eventually gain satisfaction, "what is expected." Picking up Lacan's discussion of the gaze where we left off, we are assured of the exclusive 
dependence of the gaze on the key terms of his theory-the phallus and castration: "The gaze is presented to us only in the form of a strange contingency, symbolic of what we find on the horizon, as the thrust of our experience, namely, the lack that constitutes castration anxiety" (Lacan, 72-73).

I am suggesting that the term penis and all the terms clustered around it "by a strange contingency"-phallus, lack, castration-are themselves highly charged objects for psychoanalysis, are in fact invested as what might be called discursive fetish objects. We find here again the transformation of a certain anxiety by means of the elaboration of a discourse ever more exclusive of the source of that anxiety. It is possible to see this elaboration at work in Lacan's discussion of the gaze. At one point, Lacan suggests that his interest in the scopic drive, marked by the split between the eye and the gaze, is born of the particular problems it raises for psychoanalytic theory, marked by the master term of castration: "Indeed, it is this [scopic] drive that most completely eludes the term castration" (78). This is perhaps because "of all the objects in which the subject may recognize his dependence in the register of desire, the gaze is specified as unapprehensible" (83); the gaze, in other words, cannot be represented, and thus presents a break in the closure of Lacanian theory. Such a break, or split, may explain the interest Lacan takes in the issue, but this interest is itself displaced by Lacan onto the subject himself: "I propose that the interest the subject takes in his own split is bound up with that which determines itnamely, a privileged object, which has emerged . . . from some selfmutilation induced by the very approach of the real, whose name, in our algebra, is the objet $a$ " (83). One can almost hear the sense of relief, of reasserted mastery, in those final words: "whose name, in our algebra, is the objet a."

The point I would make is that "the privileged object" is privileged as much by Lacan and the exigencies of his theory as it is by any psychoanalytic subject and that the object is whatever term (here objet a) comes to replace, and cover over, the blank space left in the "algebra" by the unrepresentable concept (here the gaze). Lacan is quite clear about the sort of satisfaction such an exercise entails: "what specifies the scopic field and engenders the satisfaction proper to it is that fact that ... the fall of the subject always remains unperceived. . . In so far as the gaze, qua object $a$, may come to symbolize this central lack 
expressed in the phenomenon of castration . . . it leaves the subject in ignorance as to what there is beyond the appearance ..." (76-77). One would like to be more precise: such a symbolization of the "unapprehensible" leaves the subject in ignorance as to the possibility that there is anything "beyond the appearance." Evidently, the scopic drive, and the gaze with which it is split, do not, after all, "elude the term castration." It is in order to provide such satisfaction that the terms of the discourse themselves become fetishized so that the discourse can continually replay the anxiety and the subsequent reassurance provided by its mastery.

The Lacanian text offers at once the illusion of an openended poetic play, and the comforting reassurance that that "play" is, in fact, rigidly controlled. The rhetoric of the text itself . . . offers the vicarious thrill of solving problems to which the answers-however difficult to find-have always been carefully pre-arranged. But the seductive power of the Lacanian text does not lie in the selfgratifying pleasure of deciphering its all too obviously calculated hermetic style. It lies, rather . . . in the metaphysical security which the text provides in the guise of an objective, "clinically proven" scientific truth: in its appeal, beyond the pleasure principle, to that desire for ontological certainty which manifests itself in the faith that man's fate, however grim, is once and for all decided. ${ }^{31}$

The account Maria Ruegg offers here of the "seductive power" of the Lacanian text suggests the way in which the allure of an "openended" discursive adventure is in fact first simulated and then replaced by its negation-by the mastery displayed in overcoming the risk of openendedness and the satisfaction that "ontological certainty" provides. This kind of mastery and satisfaction is effected through recourse to a privileged term (or set of terms) which seals off the specific discourse in question, granting a sort of closure and "ontological certainty." Like the Supreme Court with the "average person" and "community standards," the pornographers with "liberation" and "free speech," or Paul Goodman with just "it," psychoanalysis has privileged terms - the phallus, lack, castration. Once these terms are brandished, they becomes fetishized-both a source of anxiety (by their contingency to what they

31. Maria Ruegg, "Metaphor and Metonymy: The Logic of Structuralist Rhetoric," in Glyph 6 (Baltimore: Johns Hopkins University Press, 1979), 154. 
cover) and a source of reassurance (as the completing terms in a discourse which can now generate itself). Freud came close to the source of this anxiety-only to put the penis there instead. Like Griffin's "severed head," psychoanalysis ceaselessly castrates itself so that it can fill the hole in its discourse. Psychoanalysis aims to know it before it has a chance to see it.

"To the extent that it does not know repression, femininity is the downfall of interpretation." ${ }_{32}$ So writes Michèle Montrelay, and so it would appear. The long list of figures in the pornography controversy-the courts, the critics, and psychoanalysts-all fail to represent femininity. Pornography itself is the constant and desperate illusion of representing femininity. It all fails-everything represented comes, in the end, to represent masculinity. It is at this point, when the circles of male discourse seem to have completed their closure, to have become perfect mirrors of male desire and defense, that one could hope for what I have called a feminist revision, that is, an account of the relation between sexuality and representation that starts from the differential quality that relation has for men and for women. Michèle Montrelay's "Inquiry into Femininity" is such an account.

Montrelay begins with a recapitulation of the psychoanalytic debates of the 30 s on the nature of female sexuality, often referred to as the Freud-Jones controversy. Briefly, while Freud insisted on a single libidinal economy, "always male in essence," Jones and his supporters defended the notion that "feminine libido is specific": Montrelay calls the first position "phallocentric" (since for Freud, "in every case, a particular form of relation to the paternal phallus can be traced") and the second "concentric" (since Jones et al. stressed that feminine libido had a particular relation to the interior of the body and was marked by the "intrication of archaic, oral, anal and vaginal schemas") (83-85). Montrelay does not choose between these two schools of thought; rather, she sees the very contradiction "as a play of forces which structures the feminine unconscious itself" (86). This contradiction, constitutive of the feminine unconscious, always plays itself out in relation to representation.

Desire, for Montrelay, is never innate, but is rather the result of representation. In phallocentrism, representation is always in relation

32. Michèle Montrelay, "Inquiry into Femininity," tr. Parveen Adams, $m / f$, no. 1 (1978): 89 . 
to the phallus, i.e., it is a representation of castration. This all-important representation is made possible only by the repression of whatever appears as unrepresentable. In other words, the representation of castration simultaneously represses and maintains the child's relation to the unrepresentable and thus propels the child into the world of discourse, wherein desire can arise: in this "relation to the paternal phallus ... it is always a question of maintaining an inaccessible term, so that desire can subsist" (85). It was this simultaneous maintenance and exclusion of an inaccessible term that was at work in Lacan's discussion of the gaze: the gaze, "unapprehensible," and connected, moreover, to a certain feminine identity, must be both maintained, as what lies outside the Lacanian algebra, and repressed, by becoming a symbolization of castration, the objet $a$.

Montrelay allows us to see both the anxiety and the satisfaction in this operation of phallocentric representation. The anxiety arises from a confrontation with the limits of discourse itself, the unrepresentable: "anxiety appears as the limit-moment when conscious and unconscious representation are blocked off" (87); the satisfaction results from the repression of that limit-moment, that is to say, its representation. Moreover, for a phallocentric psychoanalysis (Freud, Lacan, etc.) the satisfying representation will always be one of castration, specifically, the (symbolic) castration of the phallic mother: "At bottom, it is fear of the feminine body as a non-repressed and unrepresentable object. In other words, ... femininity experienced as real and immediate, is the blind spot of the symbolic processes analysed by Freud" (92). The female body presents the threat of the unrepresentable precisely because it cannot be castrated, and hence cannot be represented as such: "Thus the sex, the vagino-oral organ of the woman, acts as obstacle to castration, falsely representing the latter in its effects of allurement which provoke anxiety" (93). It is in this sense that we can speak of psychoanalysis "castrating itself so that it can plug up the hole in its discourse": "By verbally putting into place a representation of castration, the analyst's word makes sexuality pass into discourse. This type of discourse therefore represses, at least in the sense given to the word here [i.e., as a representation that both maintains and excludes the unrepresentable object, the female body] . . . . We can ask whether psychoanalysis was not articulated precisely in order to repress femininity (in the sense of producing its symbolic representation)" (96). We might also ask whether 
the connection between pornography and the pornography controversy lies precisely in this shared goal of the repression of femininity and its concomitant "symbolic representation."

Montrelay's analysis of the phallocentric system of repression/representation also allows us to see how its unconscious effects lead to a cathexis not of the represented object (which is, after all, unrepresentable), but of the representation itself, the signifier: "Such a representation takes on an unconscious status at the moment which it no longer refers to anything but the words which constitute it. Taken out of reality, it no longer refers to anything other than its form: what is now cathected . . . is [the] specific articulation ..." (87). These specific articulations are what I have called fetishized discursive terms (phallus, castration, objet $a$, etc. - "it") which seem inevitably to reappear at those anxious, exciting, satisfying moments in the pornography controversy, and whose reiteration and substitution promotes and assures the replication of the controversy itself: "For the sequence of discourse having once marked us, endlessly reproduces itself. And we can define the unconscious as the place where these re-presentations are indefinitely staged" $(88) \cdot{ }^{33}$

33. It seems important, at this point, at least to acknowledge the fact that the term fetishism, on which I have been relying so heavily, has resonances in another vocabulary not considered in this essay, namely that of materialist critique deriving from Marx's analysis of commodity fetishism in the first volume of Capital. Alan Soble has attempted to take up the question of commodity fetishism in relation to pornography, with some convincing results, but he is also forced to stretch the meaning and mechanism of such fetishism, as Marx defined it, in order to account for some of the ideological processes I have been concerned with in this essay. Thus, he can write: "The Victorian element and the liberal element are battling each other for social power. They are competitors in the business of selling another commodity-judgment-normsand consumers are in the unenviable position of having to decide which corporation offers the best buy" (Soble, Pornography: Marxism, Feminism, and the Future of Sexuality, 76). In addition to the fact that I disagree with Soble's analysis-insofar as I argue, in my discussion of Paul Goodman, that the competition between "judgment-norms" is precisely what everyone desires, as it embodies the exciting conflict-I would also note that Soble does not adequately explain how it is that "judgment-norms" can come to be "commodities," or invested as such. Heterodox Marxist Jean Baudrillard has argued that it is precisely traditional Marxism's inability to account for such a direct investment (or fetishization) of an ideology that indicates the need to revise Marx's analysis. His revision runs as follows: "If fetishism exists it is thus not a fetishism of the signified, a fetishism of substances and values . . . which the fetish object would incarnate for the alienated subject . . . it is a fetishism of the signifier. That is to say that the subject is trapped in the factitious, differential, encoded, systematized aspect of the object. It is not the passion ... for substances that speaks in fetishism, it is the passion 
Montrelay's analysis of sexuality and representation presents us with a very powerful account of the phallocentric unconscious in which is inscribed the pornography controversy, as we have described it. But a final revision is necessary, for if phallocentrism depends upon, and is structured by, this operation of repression/representation, such an operation can be at most only half the story for women who, according to Montrelay, find themselves split by the contradiction constitutive of the feminine unconscious, the contradiction between phallocentrism and concentricity. This contradiction appears most forcefully as a distinction between repression and censorship, for what is repression of femininity for the male is censorship for the female. Censorship "is always submitted to" while repression "has the value of an act":

In fact, the obstacles the censor opposes to libidinal development appear as the result of the experiences of the Other's desire . . . . From then on, this 'blank,' this unspoken, functions like a check: the censor which is set up appears as the effect of an absence of representation .... Repression, on the contrary, presupposes a symbolization: as we have seen, it allows the representation to be cathected as such .... Repression is always a process which structures on the level of the psychic economy. (90)

We can see here the distinction between what men and women get out of pornography, both at the level of practice and at the level of discourse. For pornography (and the controversy surrounding it) is simultaneously a symbolization of female sexuality for men and the absence of such a representation for women. For women, it is the "experience of the Other's desire." And we can see the difference between the Supreme

\footnotetext{
for the code. It is the (ambivalent) fascination of a form (logic of the commodity or system of exchange value), a state of absorption, for better or for worse, in the restrictive logic of a system of abstraction" (Jean Baudrillard, "Fetishism and Ideology," in For a Critique of the Political Economy of the Sign, tr. Charles Levin [St. Louis: Telos Press, 1981], 92). It is exactly this "(ambivalent) fascination for a form" that I have tried to trace in this essay by suggesting that the "state of absorption" so common to the pornographic experience is replicated in the controversy over pornography itself. The fascination with these discourses is ambivalent because, while they ceaselessly try to bring into representation, the "restrictive logic" of the discourse depends still on a rule of exclusion. While I find Baudrillard's analysis of fetishism and ideology suggestive and convincing (in large measure), I nevertheless remain uncomfortable with what I take to be the uneasy alliance struck between a psychoanalytic and Marxist understanding of fetishism.
} 
Court and the Minneapolis ordinance replayed here as well: the repression of pornography engaged in by the Supreme Court is, as I have tried to show, a "process which structures on the level of the [male] psychic economy." On the contrary, the Minneapolis ordinance, by its invalidation of a language of female consent, "appears as the result of the Other's desire," simultaneously an "effect of an absence of representation" and the assurance that that absence "will always be submitted to."

\section{Unthinkable Postscript}

The time has come to think about sex ... [ [It] is precisely at times such as these, when we live with the possibility of unthinkable destruction, that people are likely to become dangerously crazy about sexuality.

- Gayle Rubin, Pleasure and Danger

Yet today we are faced with the greatest challenge of all! Unless we can blunt this trend toward the sexual debasement of our very own children, then nothing else of value will remain in our beloved country. Join with me now. There is simply no thinkable alternative.

- Charles Keating, Jr., Propaganda flyer for the Citizens for Decency through Law

... if the representation then does not cease to represent itself, how can it disappear? Yet the analyst must reckon with this effacement, for the patient, who expresses anxiety after the event, is speaking of a time when nothing was thinkable.

-Michèle Montrelay, "Inquiry into Femininity"

As these quotations make clear, questions of representation and sexuality, as they converge in the pornography controversy, evoke a sense of urgency or anxiety by their relation to some excluded term: the unthinkable. For Gayle Rubin, it is unthinkable nuclear destruction, for Charles Keating pornography itself is unthinkable, and for Montrelay it is the possibility that there was ever an "outside" to discourse that seems unthinkable. It is Montrelay's limit of the thinkable that this essay has striven to reach; the failure to breach definitively that limit 
may make it appear that my use of the term "discourse" has remained radically unthought. For at every step of the argument, "discourse" seems to have gotten there first, setting the terms in such a way as to repeat itself endlessly in the "restrictive logic of a system of abstraction." ${ }^{34}$ Perhaps "discourse" is my own omnipresent, excluded term. And yet, as I have tried to do in this essay, the constant task is precisely to locate oneself in relation to this unthinkable term-"discourse"-to define as adequately as possible the relations of coercion and construction between the subject and his/her limits of representation. We are both the patient and the analyst in this process, the patient overcome with "anxiety" in his relation to the unthinkable, and the analyst who must "reckon with this effacement," the possibility-necessity - of an "outside" to the discourse that seems so totally to circumscribe her. The answer is not to search for some release from representation. The answer is to try always to find the invested, fetishized terms which paper over the anxious holes in discourse itself, and to speak from there. This search for a pleasure uncoerced by discourse is itself pleasurable, for as Montrelay suggests, "Contrary to what one might think, ... pleasure does not lie in the lifting of an inhibition, ... in the releasing of a tension.... On the contrary, pleasure arises from the putting in place of new representations ..." (95).

34. Jean Baudrillard, "Fetishism and Ideology." 